Nelya V. DOROSHKEVICH ${ }^{1 *}$, Marina V. FRONTASYEVA ${ }^{2}$

Viktor S. DOROSHKEVICH ${ }^{3}$, Olena S. LYGINA ${ }^{4}$, Artem V. SHYLO ${ }^{5}$

Tatyana M. OSTROVNAYA ${ }^{2}$, Sergey S. PAVLOV ${ }^{2}$, Nadiya N. PIRKO ${ }^{6}$

Tatyana Yu. ZELENYAK ${ }^{5}$, Tatyana E. KONSTANTINOVA ${ }^{5}$

Svitlana B. LYUBCHYK ${ }^{4}$ and Aleksandr S. DOROSHKEVICH ${ }^{2,5}$

\title{
ZIRCONIA NANOPARTICLES IMPACT ON MORPHOPHYSIOLOGICAL DATA AND MINERAL COMPOSITION OF P. ostreatus
}

\author{
WPLYW NANOCZĄSTEK CYRKONU NA PARAMETRY \\ MORFOFIZJOLOGICZNE I SKŁAD MINERALNY P. ostreatus
}

\begin{abstract}
Neutron activation analysis of the Pleurotus ostreatus showed that adding of solid solution of $\mathrm{ZrO}_{2}-\mathrm{Y}_{2} \mathrm{O}_{3}$ hydroxide and oxide $\left(3 \mathrm{~mol} \% \mathrm{Y}_{2} \mathrm{O}_{3}\right)$ nanoparticles of size 4 and $9 \mathrm{~nm}$ at a concentration of 0.2 weight percent in a nutrient medium (Czapek) alters the character of physiological processes in the biological tissues of the mushrooms. This is manifested in the form of a significant change in morphological and physiological characteristics of the mushrooms and the elemental composition of the dry biomass. In particular, it is shown that the intercalation of nanoparticles into the tissues of the mushrooms leads to an increase of 1.3-1.4 times (more than $2.6 \mathrm{~g} / \mathrm{dm}^{3}$ ) of biomass accumulation (industrial strain HK 35) and decrease of 1.7-1.8 times (below $1.7-2.5 \mathrm{mg} / \mathrm{mm}^{3}$ ) of concentrations of extracellular proteins into the culture fluid at a substantially constant value of the acidity. It is shown that the addition of $\mathrm{ZrO}_{2}+3 \mathrm{~mol} \% \mathrm{Y}_{2} \mathrm{O}_{3}$ nanoparticles of sizes 4 or $9 \mathrm{~nm}$ into tissue of mushroom at step of the mother mycelium in very small concentrations can alter effectively the chemical composition of the substances produced by the cells and consequently, its physiological activity. It is shown that the use of low concentrations of $\mathrm{ZrO}_{2}$ nanoparticles allow to increase the yield and resistance of crops to diseases up to 1.2-1.5 times, as well as in the long term can be used in biomedical technologies for the treatment of cancer diseases.
\end{abstract}

Keywords: neutron activation analysis, mushroom P. ostreatus (Jacq.: Fr.) Kummer, interaction of nanoparticles with biological tissues, heavy metals sorbents, anticancer drugs

\footnotetext{
${ }^{1}$ Faculty of Biology, Donetsk National University, str. Schorsa 46, Donetsk, 83050, Ukraine

${ }^{2}$ Joint Institute for Nuclear Research, str. Joliot-Curie 6, 141980, Dubna, Russian Federation, email: mfrontasyeva@yahoo.com,doroh@jinr.ru

${ }^{3}$ Donetsk National University, Department of Biochemistry, str. Schorsa 17a, Donetsk, 83000, Ukraine, email: vikdor@mail.ru

${ }^{4}$ Universidade Nova de Lisboa, 2829-516 Caparica Ext.: 12201/3/4/5, Portugal, email: 1_lygina@yahoo.com

${ }^{5}$ Donetsk Physical-Technical Institute, OO Galkin NAS, str. R. Luxemburg 72, Donetsk, 83114, Ukraine, email: matscidep@aim.com

${ }^{6}$ Institute of Food Biotechnology and Genomics NAS, str. Osipovskii 2a, Kiev, 04123, Ukraine, email:yavp@mail.ru

*Corresponding author: nelya_dor@mail.ru
} 


\section{Introduction}

Last 10-15 years, an interest to the nanomaterials with specific properties has been significantly increased. Influence of nanoparticles on living organisms is ambiguous and still not well studied $[1,2]$. The rapid development of nanotechnology dictates the relevance of its investigation, within both the environmental and usage aspects [3]. Recently, numbers of facts pointing a significant impact of oxide nanoparticles on the processes arising in biological tissues are established. In particular, interesting effects caused by intercalation of nanoparticles are chemical modification of tissues, physiological changes in the evolution of living organisms $[3,4]$ and the "reverse effect" $[5,6]$.

Nanoparticles of metals and their oxides are not only relatively easy digested tissue of mushrooms, but in some cases are derived physiological processes in biological tissues. Application of mushrooms of the Pleurotus genus for nanoparticle synthesis is one of the major approaches of green chemistry [7, 8]. Thus, the authors of [9] shows an environmentally friendly, non-toxic and cost-effective way to obtain gold nanoparticles from aqueous medium by using the culture filtrate of the mushrooms Pleurotus sapidus as condensing and stabilizing agent.

Property of mushrooms to convert (in the physico-chemical interpretation of the word), metal ions and oxygen into the solid nanoparticles and the biologically active substances represents the multidisciplinary interest. The last has been driven by a unique combination of physicochemical and biological properties of these nanoparticles. The authors of [7] using an extract of mushroom Pleurotus florida under the influence of solar energy obtained gold nanoparticles, which possess anti-cancer properties in relation to different cancer cell lines A-549 (Human lung carcinoma), K-562 (Human chronic myelogenous leukemia bone marrow), Hela (Human cervix) and MDA-MB (Human adenocarcinoma mammary gland). Moreover, no lethal effect was found in studies in Vero for monkey kidney cells Chlorocebus aethiops (Green monkey). This refers to the high efficiency of biologically active substances synthesized in biological nano-reactors and perspective for medical aspects research. Well known that $P$. ostreatus (Jacq.: Fr.) Kummer have the ability to accumulate heavy metals in various organs and tissues [10-12]. In addition, the mushrooms of this group contain large amounts of biologically active substances and have good taste qualities [13-15]. Increase of manufacturability of mushroom biomass P. Ostreatus (Kumm) without the use of transgenic technology makes the relevance of studying the interaction of nanoparticles with mushrooms more pronounced. Thus, study of the interaction of oxide nanoparticles with biological objects on the example of mushroom P. ostreatus (Jacq.: Fr.) Kummer as are relevant from the perspective of ecological and application aspects. Mushroom P. ostreatus (Jacq.: Fr.) Kummer is a good model object, since it has high sorption properties $[16,17]$, high viability and short life cycle $[4,18]$.

The aim of this work was to establish the influence of intercalated zirconium dioxide and hydroxide nanoparticles in tissue of vegetative mycelium basidiomycete of $P$. ostreatus on its morphological and physiological parameters, and mineral composition.

\section{Materials and methods}

Work was built on comparison of biological characteristics and the atomic composition of the samples of biological material, grown on a nutrient medium with and without oxide nanoparticles. As the biological material was used the HK-35 strain and isolate SA 
basidiomycete P. ostreatus from the collection of the Department of Plant Physiology, of Donetsk National University (Ukraine).

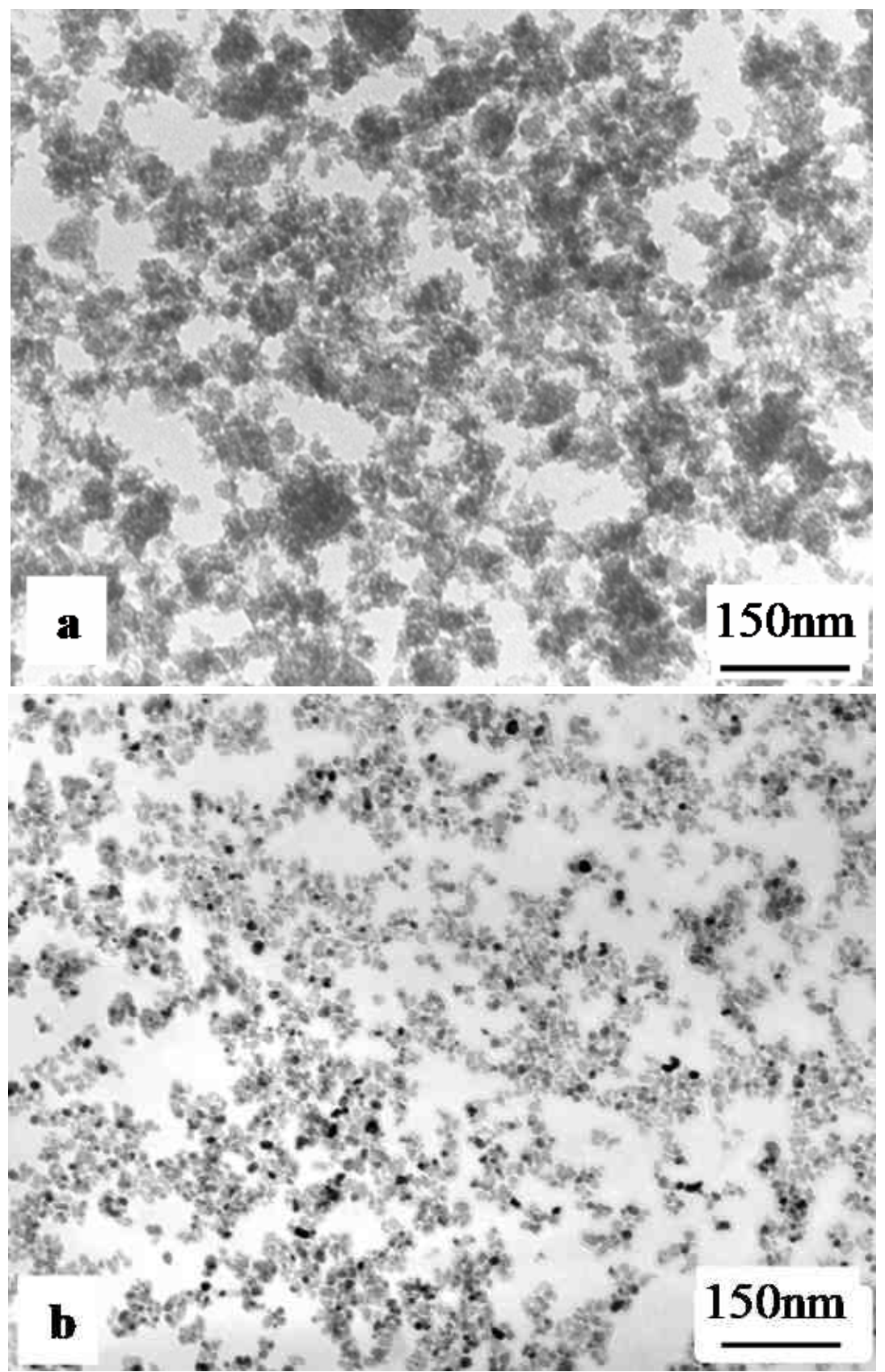

Fig. 1. TEM - pictures hydroxide (a) and an oxide (b) nanopowders of a $\mathrm{ZrO}_{2}-3$ mol $\% \mathrm{Y}_{2} \mathrm{O}_{3}$ solid solution 
Cultivation of $P$. ostreatus mycelium was carried out superficially in Erlenmeyer flasks of $250 \mathrm{~mm}^{3}$ according to standard procedure [19]. To prepare the test samples in each flask was poured with $50 \mathrm{~mm}^{3}$ of medium contained $0.1 \mathrm{~g}$ of zirconium oxide nanopowders. Two varieties of nanoparticles were used: I - Zirconium hydroxide nanoparticles: $\mathrm{ZrO}(\mathrm{OH})_{2}$ (the size of 4 nm, Fig. 1a); II - Zirconium oxide nanoparticles: $\mathrm{ZrO}_{2}$ (size 9 nm, Fig. 1b). Both sorts of nanoparticles are doped by the same amount -3 mol $\%$ of alloying element - yttrium oxide $\left(\mathrm{Y}_{2} \mathrm{O}_{3}\right)$ but different in size, degree of hydration and the level of structural organization (crystallinity). Czapek medium used for culturing the mushrooms contain $30 \mathrm{~g} / \mathrm{dm}^{3}$ of sucrose as a carbon source. Czapek's medium was prepared by the method of S. Semenov described elsewhere [20]. As control group samples were used objects without content of nanopowders in its composition. Hereinafter samples without additives and with additives nanopowders will be called the "control" and "experimental", respectively. Sterilization of the nutrient medium was carried out in an autoclave at $121^{\circ} \mathrm{C}$ under a pressure of 1.2-1.4 atm. for $45 \mathrm{~min}$. Inoculation was carried out pieces of mycelium, previously grown on standard wort-agar medium (at $4^{\circ}$ by Balling) in tubes $(20 \times 2 \mathrm{~cm}$ ) during 7 days. Cultivation time was 30 days in an incubator at $26^{\circ} \mathrm{C}$. At the end of experiment the effect of zirconium dioxide and hydroxide nanopowders on morphological parameters of mushroom (mycelium surface morphology, biomass accumulation, the ability to produce extracellular proteins, $\mathrm{pH}$ of the medium after cultivation) was evaluated.

Biomass (ratio of weight vegetative mycelium to volume of the culture liquid) $\left[\mathrm{g} / \mathrm{dm}^{3}\right]$ was determined gravimetrically. For this purpose vegetative mycelium was separated from the culture liquid (CL), washed in running water, placed in a metal weighing bottles and dried in an oven at $105^{\circ} \mathrm{C}$ until a constant weight [19]. The total amount of extracellular proteins was measured spectrophotometrically (after G.A. Kochetov) [21]. The concentration of hydrogen ions in CL was determined by potentiometer $\mathrm{pH}-150 \mathrm{M}$. The concentration of mineral elements in the biomass was determined by epithermal neutron activation analysis at the IBR-2 in Joint Institute of Nuclear Research (JINR, Dubna, Russia) [22-24]. Multiplicity of experimental replicates was 3. Statistical processing the obtained experimental data was performed using the computer program Statistica 6.0.

\section{Results and analysis}

Effect of zirconium oxide nanoparticles on morphology of mycelium samples. Figure 2 shows photographs of mycelium samples of the mushrooms grown in liquid medium without additives (Fig. 2a), and with addition of nanopowders of various degrees of structural organization (Fig. 2b, c) (hydroxide and oxide, respectively). It is seen that the control and experimental samples have pronounced morphological differences. Mycelium of control sample (Fig. 2a) has a form of fragments of lamella and semitransparent. Experimental samples (Fig. 2b, c) have a lower degree of transparency and more dense in comparison with the control. At the touch the control sample of mycelium is soft, mucous and easily divided into segments. Myceliums of samples with nanopowders are tighter and compacted in the form of lumps. 

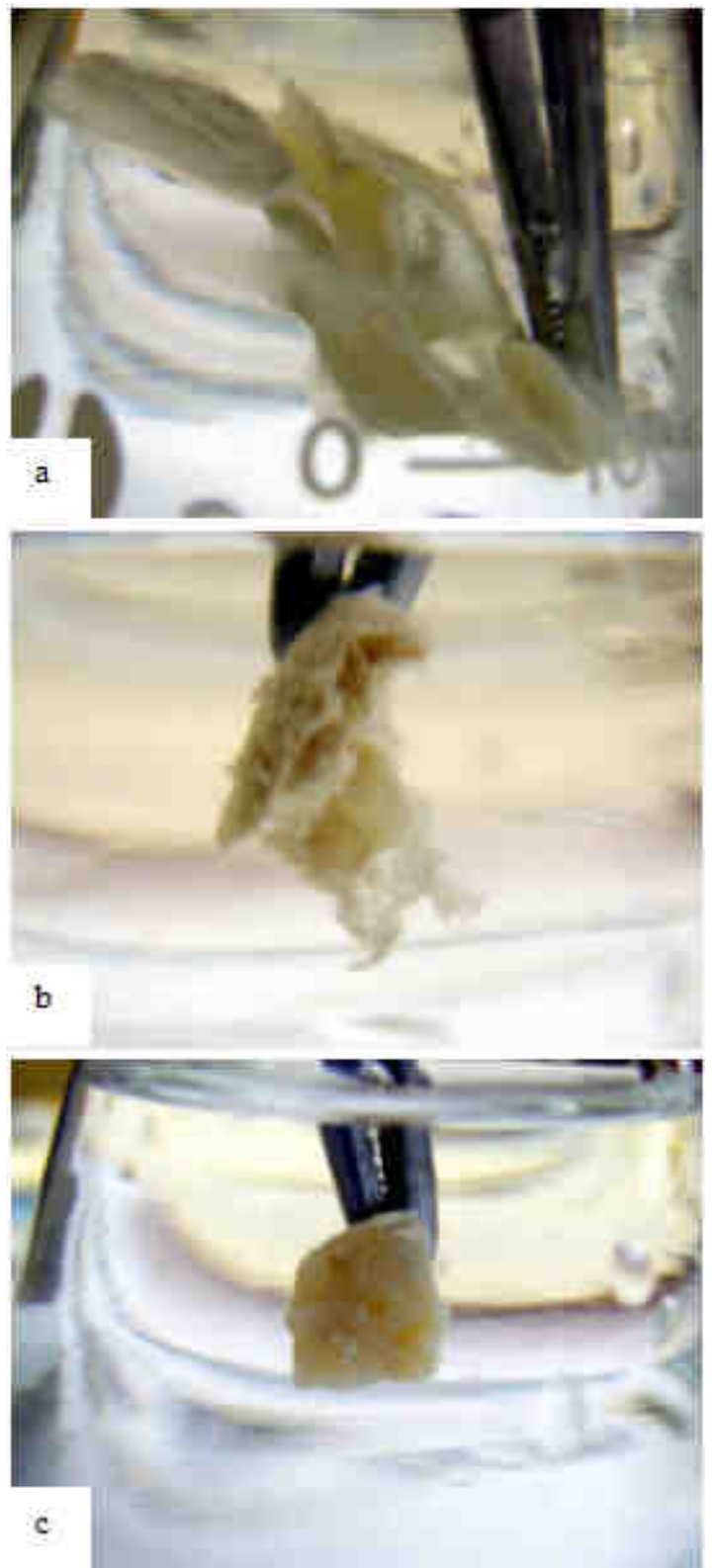

Fig. 2. Morphological peculiarities of the samples vegetative mycelium of the P. ostreatus mushrooms: without added nanopowders (a), and with the addition of the oxide (b) and zirconium hydroxide (c) nanopowders

Influence of oxide nanoparticles on physiological indices of mycelium samples. Figures 3-5 are diagrams of physiological parameters for the control and experimental samples of mycelium of mushrooms $P$. ostreatus. 
Figure 3 shows that addition of oxide nanopowders to the culture medium led to increased accumulation of mushroom $P$. ostreatus biomass $1.3-1.4\left(2.7-3.0 \mathrm{~g} / \mathrm{dm}^{3}\right)$ and 1.2-1.6 (1.4-1.8 $\left.\mathrm{g} / \mathrm{dm}^{3}\right)$, relative to the control sample respectively, for the strains of HK-35 and SA-fold. It worth noting that the accumulation of biomass for strain HK-35 was in 1.7-1.8 times higher compared with the isolate SA for both control and experimental samples (2.1-3.0 and 1.1-1.8 g/dm ${ }^{3}$, respectively). Consequently, the strain HK-35 and SA isolate reacted differently to the presence of nanopowders in the culture medium, indicating their individual characteristics.

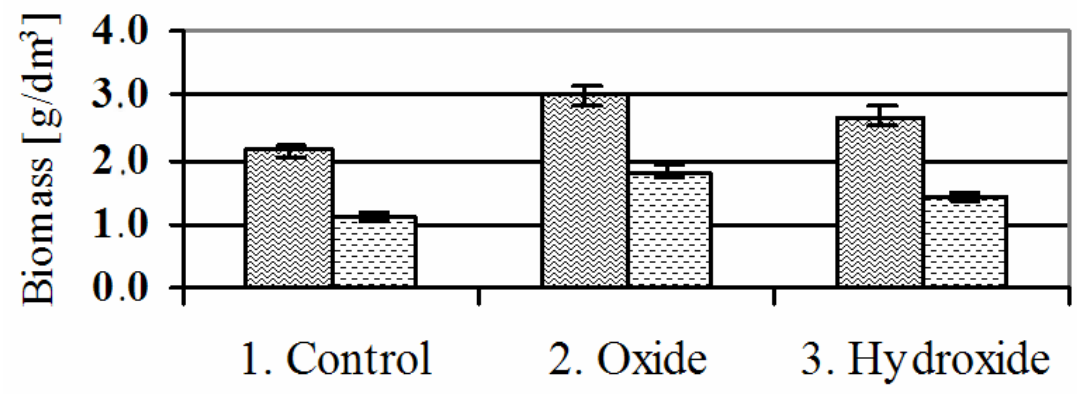

\section{图 HK-35 圖 SA}

Fig. 3. Biomass accumulation of HK-35 and SA strains of $P$. ostreatus mushrooms, cultivated on culturing medium without adding nanopowders (1), with addition of the oxide (2) and zirconium hydroxide (3) nanopowders

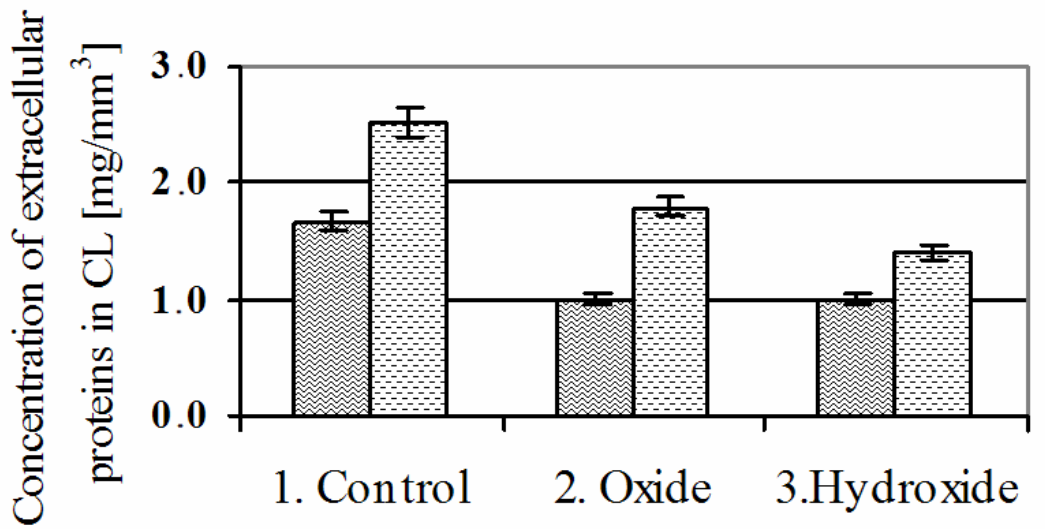

\section{图 HK-35 웅 SA}

Fig. 4. Concentration of extracellular proteins in CL of HK-35 and SA strains of P. ostreatus mushrooms, cultivated on culturing medium without adding nanopowders (1), with addition of the oxide (2) and zirconium hydroxide (3) nanopowders 
Figure 4 shows that the concentration of extracellular proteins in CL samples of mushrooms $P$. ostreatus, by adding the nanopowder in the culture medium decreased up to 1.7-1.8 times compared with the control batch of samples (for HK-35 from 1.7 to $1,0 \mathrm{mg} / \mathrm{mm}^{3}$ and for SA from 2.5 to $\left.1.4 \mathrm{mg} / \mathrm{mm}^{3}\right)$. Moreover, a larger number of extracellular proteins in CL singled out isolate SA $\left(1.8-2.5 \mathrm{mg} / \mathrm{mm}^{3}\right)$. For HK-35 this value was within $1.0-1.7 \mathrm{mg} / \mathrm{mm}^{3}$.

Thus, it can be concluded that nanopowders have an impact on the enzyme system of mushroom $P$. ostreatus, suppressing the production of several enzymes. Also, it can be assumed that nanopowders can "mechanically" impede the secretion of proteins by cells of mushroom $[25,26]$. Thus, the addition of oxide nanopowders to the culture medium causes a change in the surface morphology of the mycelium increasing the accumulation of biomass (on Czapek's medium) and inhibits secretion of extracellular proteins in CL. Figure 5 shows that the $\mathrm{pH}$ of the $\mathrm{CL}$ after cultivation in media with the addition nanopowders decreased by about 2-5\% compared with the control.

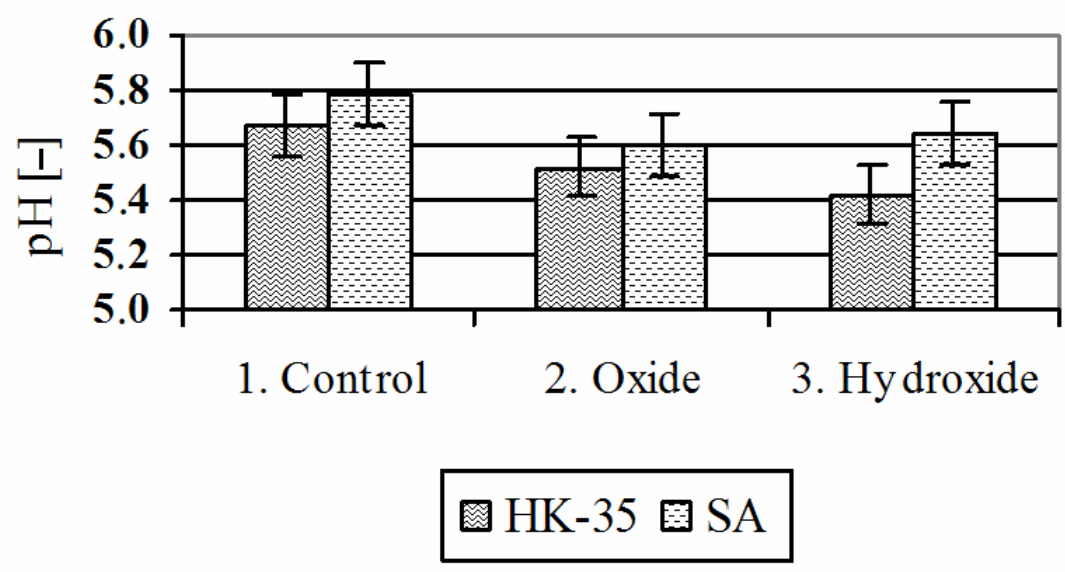

Fig. 5. The $\mathrm{pH}$ of $\mathrm{CL}$ of HK-35 and SA strains of $P$. ostreatus mushrooms, cultivated on culturing medium without adding nanopowders (1), with addition of the oxide (2) and zirconium hydroxide (3) nanopowders

The influence of oxide nanoparticles on the mineral composition of the samples of mycelium. Table 1 shows the quantitative evaluation of chemical elements in the surface of mycelium of mushroom $P$. ostreatus, after cultivation in nutrient media with and without nanopowders by using NAA method. It is seen (Table 1) that the addition to the culture medium of oxide nanopowders significantly modifies the content of mineral elements in the superficial biomass of the mycelium of mushroom $P$. ostreatus. The highest amount of mineral elements, in particular, Hf and $\mathrm{Zr}$, was in test samples. Their concentration is higher than the corresponding value in the control samples of more than 1000 times. This fact indicates a high sorption capacity of investigated type of mushroom to these elements. 
The elemental composition of the dry biomass of the mushroom $P$. ostreatus according to NAA method [mg/kg]

\begin{tabular}{|c|c|c|c|c|c|c|}
\hline \multirow[b]{2}{*}{$\mathbf{R}^{*}$} & \multicolumn{6}{|c|}{ Sample } \\
\hline & HK-35 (control) & HK-35 $\left(\mathrm{ZrO}_{2}\right)$ & $\begin{array}{c}\mathrm{HK}-35 \\
\left(\mathrm{ZrO}(\mathrm{OH})_{2}\right) \\
\end{array}$ & SA (control) & $\mathrm{SA}\left(\mathrm{ZrO}_{2}\right)$ & $\begin{array}{c}\text { SA } \\
\left(\mathrm{ZrO}(\mathrm{OH})_{2}\right) \\
\end{array}$ \\
\hline $\mathbf{N a}$ & $7280 \pm 728$ & $5820 \pm 582$ & $5400 \pm 540$ & $5600 \pm 560$ & $3640 \pm 364$ & $4820 \pm 482$ \\
\hline Mg & $244 \pm 24$ & $240 \pm 24$ & $262 \pm 26$ & $269 \pm 27$ & $222 \pm 22$ & $398 \pm 40$ \\
\hline $\mathbf{A l}$ & $32 \pm 3$ & $40 \pm 3$ & $36 \pm 3$ & $26.7 \pm 2.1$ & $60.7 \pm 4.9$ & $104 \pm 8$ \\
\hline $\mathbf{S}$ & $2010 \pm 804$ & $1650 \pm 660$ & $7280 \pm 2912$ & $5520 \pm 22$ & $3660 \pm 1464$ & $3690 \pm 1476$ \\
\hline $\mathrm{Cl}$ & $11200 \pm 784$ & $10500 \pm 735$ & $9750 \pm 682$ & $11300 \pm 791$ & $8510.0 \pm 596$ & $8030 \pm 562$ \\
\hline $\mathbf{K}$ & $16000 \pm 1280$ & $14700 \pm 1176$ & $14400 \pm 1152$ & $17600 \pm 1408$ & $12600 \pm 1008$ & $14700 \pm 1176$ \\
\hline $\mathbf{C a}$ & $1830 \pm 128$ & $1210 \pm 85$ & $1110 \pm 78$ & $4100 \pm 287$ & $2080 \pm 146$ & $3840 \pm 269$ \\
\hline Sc & $0.013 \pm 0.004$ & $0.13 \pm 0.04$ & $0.5 \pm 0.2$ & $0.02 \pm 0.01$ & $1.1 \pm 0.3$ & $0.9 \pm 0.3$ \\
\hline $\mathbf{V}$ & $0.09 \pm 0.04$ & $0.12 \pm 0.05$ & $0.08 \pm 0.03$ & $0.10 \pm 0.04$ & $0.07 \pm 0.03$ & $0.17 \pm 0.07$ \\
\hline Mn & $1.2 \pm 0.1$ & $0.94 \pm 0.09$ & $0.64 \pm 0.06$ & $1.5 \pm 0.2$ & $1.25 \pm 0.12$ & $1.9 \pm 0.2$ \\
\hline $\mathrm{Fe}$ & $27 \pm 5$ & $29 \pm 6$ & $22 \pm 4$ & $35 \pm 7$ & $94 \pm 19$ & $34 \pm 7$ \\
\hline $\mathrm{Ni}$ & $0.9 \pm 0.4$ & $0.6 \pm 0.3$ & $0.3 \pm 0.1$ & $1.1 \pm 0.5$ & $1.3 \pm 0.5$ & $9.8 \pm 3.9$ \\
\hline Co & $0.04 \pm 0.01$ & $0.04 \pm 0.01$ & $0.07 \pm 0.01$ & $0.05 \pm 0.01$ & $0.13 \pm 0.02$ & $0.18 \pm 0.04$ \\
\hline $\mathbf{C u}$ & $20 \pm 6$ & $8 \pm 3$ & $17 \pm 5$ & $25 \pm 8$ & $17 \pm 5$ & $12 \pm 4$ \\
\hline $\mathbf{Z n}$ & $5.0 \pm 0.7$ & $3.8 \pm 0.6$ & $3.1 \pm 0.5$ & $6.5 \pm 1.3$ & $3.9 \pm 0.6$ & $4.6 \pm 0.7$ \\
\hline As & $1.2 \pm 0.2$ & $4.3 \pm 0.6$ & $4.6 \pm 0.7$ & $1.6 \pm 0.2$ & $13 \pm 2$ & $22 \pm 4$ \\
\hline $\mathbf{S e}$ & $7.8 \pm 0.8$ & $11 \pm 1$ & $5.0 \pm 0.5$ & $10 \pm 1$ & $9.7 \pm 1,0$ & $2.3 \pm 0.2$ \\
\hline $\mathbf{B r}$ & $20 \pm 2$ & $17 \pm 2$ & $13 \pm 2$ & $25 \pm 3$ & $18 \pm 2$ & $13 \pm 2$ \\
\hline $\mathbf{R b}$ & $0.7 \pm 0.2$ & $0.5 \pm 0.1$ & $0.7 \pm 0.1$ & $0.6 \pm 0.1$ & $0.4 \pm 0.1$ & $0.34 \pm 0.01$ \\
\hline $\mathbf{S r}$ & $25.9 \pm 2.5$ & $17 \pm 7$ & $59 \pm 24$ & $32 \pm 13$ & $54 \pm 21$ & $61 \pm 24$ \\
\hline $\mathbf{Z r}$ & $26 \pm 8$ & $40500 \pm 12150$ & $75100 \pm 22530$ & $34 \pm 10$ & $107000 \pm 32100$ & $126000 \pm 37800$ \\
\hline $\mathbf{A g}$ & $0.12 \pm 0.01$ & $0.06 \pm 0.01$ & $0.57 \pm 0.06$ & $0.15 \pm 0.02$ & $4.5 \pm 0.5$ & $1.0 \pm 0.1$ \\
\hline Sb & $0.04 \pm 0.01$ & $0.06 \pm 0.01$ & $0.05 \pm 0.01$ & $0.03 \pm 0.02$ & $0.03 \pm 0.01$ & $0.05 \pm 0.01$ \\
\hline I & $2.5 \pm 1.0$ & $5.4 \pm 2.2$ & $7.5 \pm 3.0$ & $2.5 \pm 1,0$ & $13 \pm 5$ & $15 \pm 6$ \\
\hline Cs & $0.29 \pm 0.01$ & $0.21 \pm 0.01$ & $0.12 \pm 0.01$ & $0.22 \pm 0.01$ & $0.09 \pm 0.01$ & $0.09 \pm 0.01$ \\
\hline La & $0.16 \pm 0.05$ & $0.5 \pm 0.2$ & $0.6 \pm 0.2$ & $0.21 \pm 0.06$ & $0.7 \pm 0.2$ & $0.8 \pm 0.2$ \\
\hline $\mathrm{Ce}$ & $2.7 \pm 0.8$ & $9.0 \pm 2.7$ & $13 \pm 4$ & $3.5 \pm 1.1$ & $20 \pm 6$ & $19 \pm 6$ \\
\hline Nd & $6.2 \pm 2.5$ & $291 \pm 116$ & $473 \pm 189$ & $8 \pm 3$ & $776 \pm 310$ & $689 \pm 276$ \\
\hline Sm & $0.02 \pm 0.01$ & $0.02 \pm 0.01$ & $0.10 \pm 0.03$ & $0.02 \pm 0.01$ & $0.27 \pm 0.08$ & $0.03 \pm 0.01$ \\
\hline Eu & $0.07 \pm 0.02$ & $0.3 \pm 0.1$ & $0.3 \pm 0.1$ & $0.10 \pm 0.03$ & $0.27 \pm 0.08$ & $0.3 \pm 0.1$ \\
\hline Dy & $0.6 \pm 0.2$ & $0.46 \pm 0.18$ & $0.5 \pm 0.2$ & $0.5 \pm 0.2$ & $1.5 \pm 0.6$ & $1.6 \pm 0.6$ \\
\hline Hf & $0.47 \pm 0.14$ & $931 \pm 279$ & $1690 \pm 507$ & $0.61 \pm 0.18$ & $2430 \pm 729$ & $2820 \pm 846$ \\
\hline $\mathrm{Hg}$ & $0.55 \pm 0.21$ & $3.8 \pm 1.5$ & $6.3 \pm 2.5$ & $0.7 \pm 0.3$ & $15 \pm 6$ & $10 \pm 4$ \\
\hline Th & $0.02 \pm 0.01$ & $0.15 \pm 0.02$ & $0.23 \pm 0.03$ & $0.027 \pm 0.004$ & $0.45 \pm 0.07$ & $0.6 \pm 0.1$ \\
\hline $\mathbf{U}$ & $0.45 \pm 0.05$ & $0.67 \pm 0.07$ & $0.74 \pm 0.07$ & $0.59 \pm 0.05$ & $1.1 \pm 0.2$ & $1.2 \pm 0.1$ \\
\hline
\end{tabular}

* Note: R - mineral element

It should be noted that the susceptibility of the studied objects to $\mathrm{Zr}$ and $\mathrm{Hf}$ is different. The best sorption capacity has isolate SA. For SA concentrations of these elements higher than the corresponding value for strain HK-35 in the control group (30\%) and in the experimental (1.7-2.6 times) groups of the samples. Accumulation of zirconium in amounts in test samples, obviously related to the fact that it is contained in the composition of the solid solution introduced into the medium nanoparticles. Addition of oxide nanoparticles lead to accumulation in superficial biomass of the mushrooms (such as SA and HK-35) Sc, $\mathrm{Nd}, \mathrm{Hg}$ and $\mathrm{Th}$ in an amount exceeding the reference values more than 10 times. The content of neodymium in the isolate SA exceed the reference values more than a factor of 
$100(689-776 \mathrm{mg} / \mathrm{kg})$. As in the case of $\mathrm{Zr}$ and $\mathrm{Hf}$, Isolate SA exhibited higher sorption capacity for said elements. Their quantity in superficial biomass of isolate SA was higher than corresponding values for strain $\mathrm{HK}$ - 35 up to 1.5-8.6 times. Increase of the scandium concentration of more than 10 times, is no coincidence, because it is a part of the base enzymes in the mushrooms $[18,19]$. It can be assumed that nanopowders induce production of specific enzymes for better absorption of the nutritional medium with zirconia nanoparticles, which lead to increase of biomass accumulation compared to the control (Fig. 3). Moreover they also prevent the formation of special protein metabolites, which lead to a decrease of amount of extracellular proteins in CL compared with the control (Fig. 4).

Absorption of nanopowders by mushroom mycelium has led to increase in more than 2 times compared with the control sorption Co, As, Sr, Ag, I, La, Ce, Sm, Eu and U. The exceptions can be attributed sorption of $\mathrm{Co}, \mathrm{Ag}$ and $\mathrm{Sr}$ strain HK-35 on medium containing zirconium oxide. Amount of Co was $0.04 \mathrm{mg} / \mathrm{kg}$ and did not differ from control, and the amount of $\mathrm{Ag}$ and $\mathrm{Sr}$ was $1.5-1.8$ less $(0.06$ and $17 \mathrm{mg} / \mathrm{kg}$, respectively) than the control $(0.12$ and $25 \mathrm{mg} / \mathrm{kg}$, respectively). It is known that chemical elements $\mathrm{La}, \mathrm{Ce}, \mathrm{Nd}, \mathrm{Sm}, \mathrm{Eu}$, and $\mathrm{Hf}$ are rare earth metals, Th and $\mathrm{U}$ - radioactive metals as $\mathrm{Hg}$ - to liquid metals [27, 28]. Based on the research results, increased sorption capacity of mushroom to these elements as a result of nanopowders can then be used to extract rare and toxic elements. Obviously, modification tissues of the mushrooms by nanoparticles oxide can be used to develop highly efficient methods for purifying soils from radioactive and toxic elements.

Increased content of heavy elements in the mycelium significantly decreases the nutritional value of mushrooms, however, detected amount of these toxic elements does not exceed the maximum allowable concentrations according to the regulations of the Russian Federation [29]. Special interest is changes in the quantitative composition of the vital groups of light elements.

The content of the macroelements. According to Table 1 the interaction of oxide nanoparticles in the tissue surface mycelium leads to a decrease by $10-40 \%$ of control values macroelements content of $\mathrm{Na}, \mathrm{S}, \mathrm{Cl}, \mathrm{K}$ and $\mathrm{Ca}$. Exceptions were the elements of $\mathrm{S}$ and $\mathrm{Mg}$. Sulfur in the mycelium of the strain HK-35 comprising nanoparticles of zirconium hydroxide was found 3.6 times higher $(7280 \mathrm{mg} / \mathrm{kg})$ compared to control $(2010 \mathrm{mg} / \mathrm{kg})$. The magnesium content of the mycelium HK-35 was the same as in the control series of samples (244-262 mg/kg). In the mycelium of isolate SA nanoparticles $\mathrm{ZrO}_{2}$ its content was less than 1.2 times $(222 \mathrm{mg} / \mathrm{kg})$, and the nanoparticles $\mathrm{ZrO}(\mathrm{OH})_{2}-1.5$ times as much $(398 \mathrm{mg} / \mathrm{kg})$ than in the control samples Series $(269 \mathrm{mg} / \mathrm{kg})$.

The content of the microelements. The tendency to decrease (1.1-3.1 times, Table 1) the content of light elements in the tissues of the mycelium of mushrooms P. ostreatus after intercalations nanoparticles revealed as for microelements $\mathrm{Cu}, \mathrm{Zn}, \mathrm{Br}, \mathrm{Ru}, \mathrm{Sr}$, and $\mathrm{Cs}, \mathrm{Mn}$, Se. Exceptions were the elements $\mathrm{Ni}$, Se (particle $\mathrm{ZrO}_{2}$ ) and $\mathrm{Mn}$ (particle $\mathrm{ZrO}(\mathrm{OH})_{2}$ ). In the mycelium of isolate SA on medium with nanoparticles $\mathrm{ZrO}_{2} \mathrm{Ni}$ content was the same as in the control series (1.3 and $1.1 \mathrm{mg} / \mathrm{kg}$, respectively). The Mn content is increased in SA isolate on $30 \%$ relative to the control samples of the series after the absorption of nanoparticles $\mathrm{ZrO}(\mathrm{OH})_{2}$ (respectively 1.9 and $1.5 \mathrm{mg} \mathrm{kg}$ ). Selenium content in tissues mycelium of strain $\mathrm{HK}-35, \mathrm{ZrO}_{2}$ nanoparticles exceeds control value of 1.4 times (11.0 and $7.8 \mathrm{mg} / \mathrm{kg})$. 
Overall results of analysis. The mechanism of nanoparticles influence on physiological processes in samples. Reducing the concentration of monovalent ions (K, $\mathrm{Na}, \mathrm{Cl}$ ) may indicate redistributing liquids between cells and the extracellular space, and changes in osmotic potentials. Therefore, the mechanism of physical modification in tissues of mushroom connected with the change ion transport functions of intracellular membranes.

Accumulation of $\mathrm{Mn}$ and I supposedly indicating the activation of redox processes [30]. Microelements copper, zinc, manganese, bromine, selenium, rubidium, and nickel are part of enzymes and are involved in activation. Therefore, the reduction of their content in the investigated objects the superficial surface biomass may be the result suppression of the production of extracellular enzymes (Fig. 4). However, a disadvantage in their superficial biomass does not lead to a decrease of the accumulated biomass (Fig. 3). Apparently, nanopowders in the cultivation medium make it possible to mobilize the organism of mushroom and to use the ability to include other mechanisms and elements for better absorption of the nutrient medium and to provide its life activity. It is known that mushrooms have the ability to accumulate a very high concentrations of toxic and heavy metals [31]. In response to the impact of heavy metals in the course of evolution in the cells of all organisms include detoxification mechanisms. Is binding and isolation of toxic metal ions with preservation of biological structures of the cell. The key role is in the neutralization of heavy metals is carried out special sulfur containing proteins metallothionein (MT). Synthesis of this type of proteins is induced in receipt in an organism essential as $\mathrm{Cu}$ and $\mathrm{Zn}$, and in response to receipt of $\mathrm{Cd}, \mathrm{Hg}, \mathrm{Au}, \mathrm{Ag}, \mathrm{Co}, \mathrm{Ni}, \mathrm{Pb}$ and at least some other toxic metals. However, metals such as $\mathrm{Ca}, \mathrm{Al}, \mathrm{Na}, \mathrm{Mg}, \mathrm{U}$ does not cause induction of metallothionein [32].

To elucidate realization of such a mechanism in the studied mushrooms was studied the relationship between the content of sulfur, heavy metals and extracellular proteins which were in the cultivation medium with the addition nanopowders oxide or zirconium hydroxide. Data analysis by metal content showed that the concentration of $\mathrm{Al}, \mathrm{Ca}, \mathrm{Hg}, \mathrm{Sc}$, $\mathrm{V}, \mathrm{Sr}, \mathrm{La}, \mathrm{Ce}, \mathrm{Sm}, \mathrm{Eu}, \mathrm{Th}, \mathrm{Dy}, \mathrm{U}$ was significantly higher than in control samples $P$. ostreatus. In the studied strains HK-35 and SA marked the highest level of accumulation of $\mathrm{Zr}$ and Hf. Their content was $3.4 \cdot 10^{3}$ and $4.2 \cdot 10^{3}$ times higher than in the control group samples. According to our data, $P$. ostreatus accumulate significant amounts of elements and a strong battery of heavy metals on the substrate enriched in trace elements [33].

Physiologically important microelements $\mathrm{Zn}, \mathrm{Cu}, \mathrm{Mn}, \mathrm{Fe}, \mathrm{Ni}$ in strain $\mathrm{HK}-35$ are present in smaller quantities than in samples of the control group, and for their amount of strain SA may differ in several times. Comparing strains, it can be seen that the sorption capacity for toxic metals $\mathrm{Hg}, \mathrm{Ag}, \mathrm{Nd}, \mathrm{Sc}$ in $\mathrm{HK}-35$ is lower than that of wild strain SA. It is also important that the detection of the initial amount of these elements in the mycelium of isolate SA 1.1-1.3 times more than compared with the strain HK-35. This can be explained by the fact that SA isolate received from the fruiting bodies found in the city of Donetsk, which is known for its anthropogenic load. At the same time attracts attention a decrease content $\mathrm{S}$ in the superficial mycelium with the addition of nanopowders. Therefore, detoxification function from HK-35 is better developed.

Effect of increasing the biomass of mushrooms grown with oxide nanopowders and changing parameters of morphological can probably be explained by varying the amount and structure of the protein of mushroom due to modifications of enzyme system. And, judging by the data NAA (Table 1), sulfur-containing proteins play an important role here. 
If an operating time of the protein with more sulfur containing amino acids such as cysteine and cystine, the formation of a globular protein structure occurs under the influence of the disulfide bonds. In such instances the consistency of the protein, usually compacted and become sinewy, that according to Figure 2 takes place in this case. Decrease of the extracellular proteins represented in mostly enzymes can also decreases due to suppression of the synthesis of heavy metals. For example, the enzyme laccase in mushroom, it is also copper-bearing oxidase (one molecule of the enzyme accounts for up to 4 atoms of copper), catalyzes the reduction of $\mathrm{O}_{2}$ to $\mathrm{H}_{2} \mathrm{O}$. During laccase deactivating the density may change due to the decrease of water content in the mushroom that actually shows the experiment. Furthermore laccase in inactivated $P$. ostreatus are manganese-dependent peroxidase, which participates in the oxidation of phenolic compounds by the action of hydrogen peroxide in the presence of manganese ions. The toughest/dry mushroom is strain HK-35 cultured with the addition zirconium oxide nanoparticles. The content of $\mathrm{Mn}$ is lower than for the control, which also indirectly confirms the assumptions about the mechanisms of interaction of oxide nanoparticles of varying degrees of structural order with biological tissues by the example of mushroom $P$. ostreatus. Both mechanisms indicate that as a result of the oxide nanoparticles in the tissues of mushroom the enzymatic activity is suppressed, the oxidation of organic substrates is attenuated, broken processes of hydroxylation, oxygen transfer, electron transport and oxidative catalysis.

Despite the decrease in the functional activity of enzymes and accumulation of large amounts of harmful and heavy metals ( $\mathrm{Co}, \mathrm{Hg}, \mathrm{Sc}, \mathrm{V}, \mathrm{Sr}, \mathrm{Ce}, \mathrm{Sm}, \mathrm{Eu}, \mathrm{Th}, \mathrm{Dy}$, and U), both strains studied of mushroom $P$. ostreatus content in excess of zirconium compounds actively accumulating biomass. This is indicative of the detoxification mechanism harmful elements $\mathrm{Zr}$ and direct participation in these processes. The role of zirconia, as well as other metals with variable oxidation state $(\mathrm{Cu}, \mathrm{Fe})$ can be to participate in the process of joining the electrons to oxygen with subsequent formation of active forms - the superoxide radical, hydroxyl radical, singlet oxygen, and others. As a rule, increased metal content with a variable degree of oxidation contributes to the generation of reactive oxygen species (ROS). Consequently, P. ostreatus, containing protein and enriched ROS may find application in medicine, for example for the treatment of diseases of the skin and mucous membranes, such as stomach cancer.

Correlation analysis results. Studies have revealed an interesting dependence between elements accumulation in superficial biomass. Direct correlation with a high coefficient $(R>0.80)$ mounted between macrocells sodium and potassium with $R=0.94$, between sodium and chlorine to $R=0.94$ (Fig. 6) between the magnesium and calcium $R=0.85$. This indicates the presence of a synergistic interaction between them, and as a result, a functional role for the organism. Established anti-correlation $(R>-0.90)$ mercury and sodium coefficient $R=-0.98$, mercury and potassium with $R=-0.91$ (Fig. 7), mercury and chlorine with $R=0.90$ indicates a high antagonism of these elements. Revealed a direct correlation relationship between uranium and thorium high coefficient $R=0.99$ (Fig. 8) indicates a correct geochemical ratio thorium to uranium 2:1. 


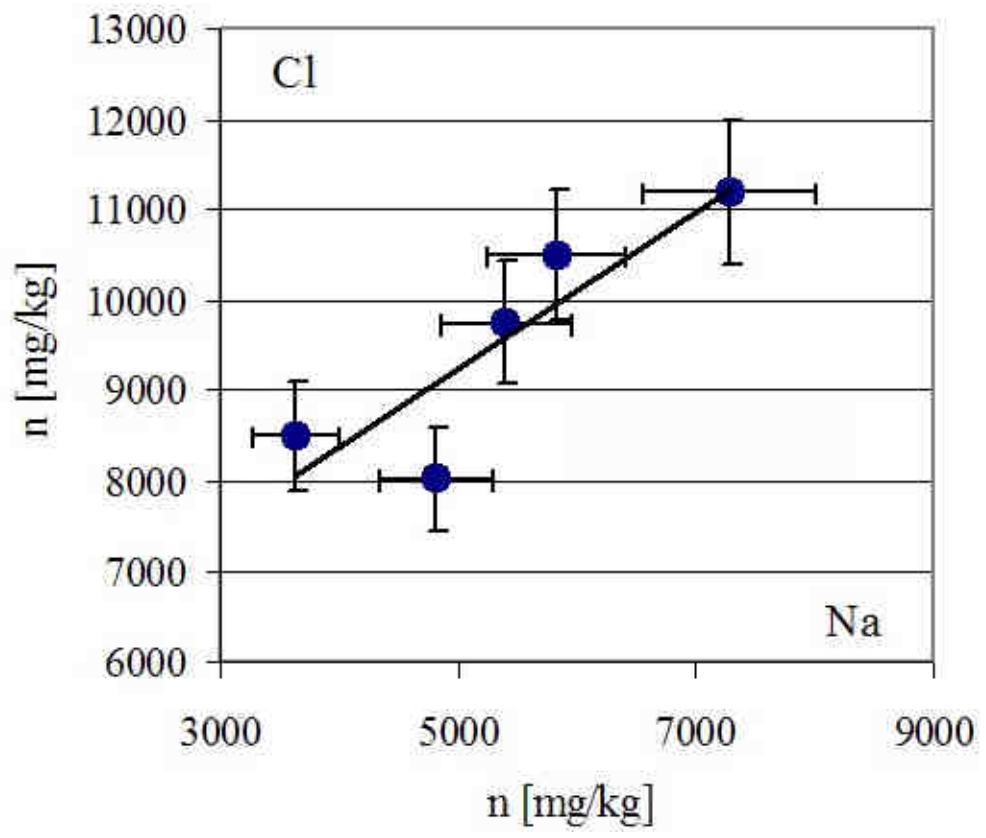

Fig. 6. The relationship between concentrations $n$ of sodium and chlorine $R=0.94$

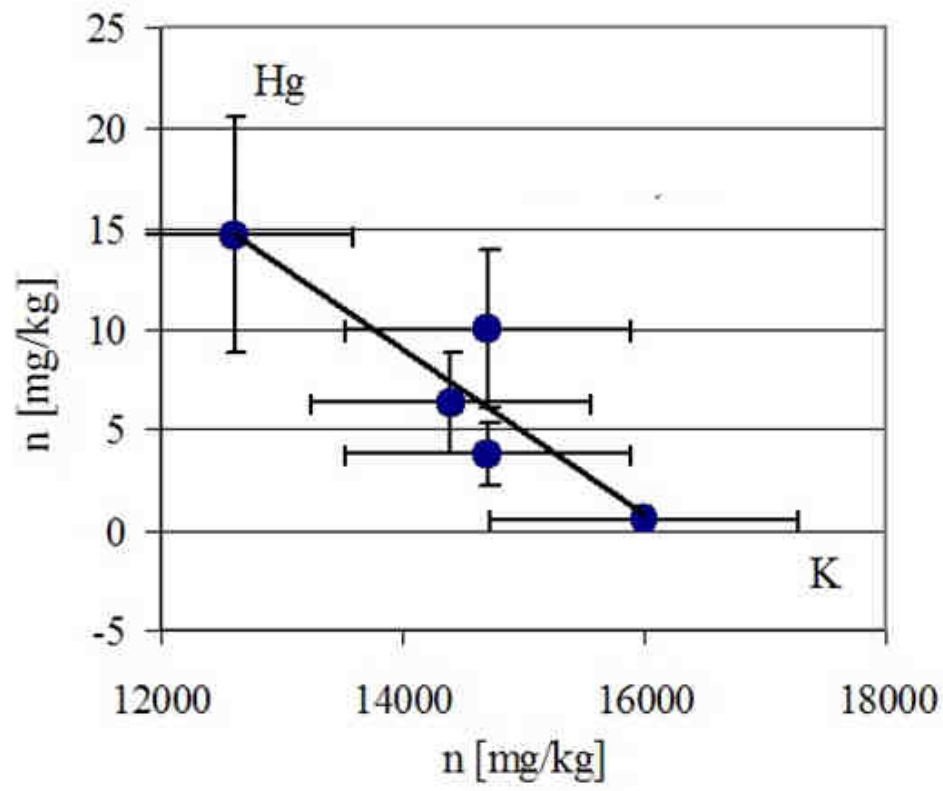

Fig. 7. The relationship between the mercury and potassium $R=0.91$ 


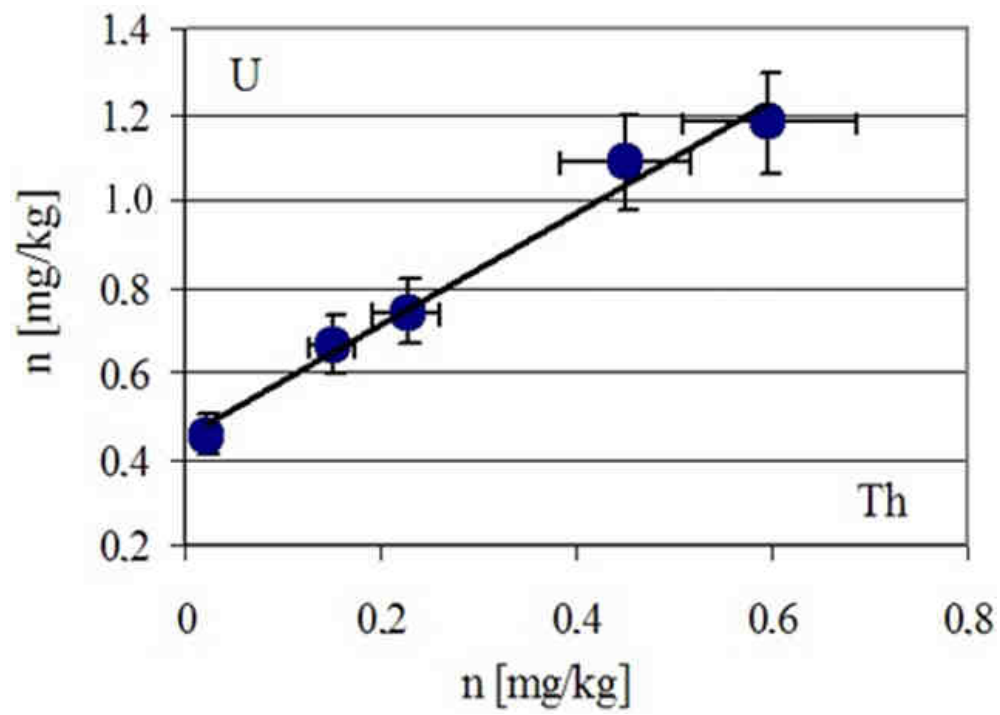

Fig. 8. The relationship between uranium and thorium $R=0.99$

Physical mechanisms of nanoparticles influence on biological cells. According to the presented results in zirconium oxide and hydroxide nanoparticles initiated changes of physiological parameters of mushroom and its enzyme system, the chemical composition of proteins and tissues.

The reason for these changes is the transport function intercellular membranes. Above is presented a possible mechanism of the effect from biochemical point of view. If we consider the influence of nanoparticles on biological objects from the positions of physics, it can be assumed that the appropriate mechanism is in "plugging" of ion channels in intercellular membranes. In this case, there is physical limitation on the size of the ion, which in turn leads to the appearance selective permeability and changing ion transport membrane function [26]. Nevertheless, character of influence to biological tissues oxide and hydroxide nanoparticles indicates that the size is not the determining factor. It is obviously that the effects of the interaction of hydroxide nanoparticles with tissues of mushroom expressed more strongly than in the case of the oxide particles. Probably, besides the size, there are still impact factors of the physical nature. Let us consider them in more detail.

Reactions implants (nanoparticles) with a biological cell according to [34] are dependent on several factors in particular the chemical composition, crystallographic structure, and the number of phases at the interface. Zirconium hydroxide and oxide from a physical point of view - is the unit of the same substance but in different stages of the structural evolution. For understanding the mechanisms of interaction with biological objects, properly consider process of formation nanoparticles based on its initial stages.

Structural organization of zirconium hydroxide nanoparticles. As is known, the elements of the fourth subgroup of the periodic table have a tendency to polymerize. Polymerization of elementary structural elements - tetrameters starts even in the process merging fluids of chemical reagents in conditions of significant satiety relatively forming phase [35]. As a result, a number of physical and chemical processes the tetramers 
$\left[\mathrm{Zr}_{4} \mathrm{O}_{2}(\mathrm{OH})_{4}\right]^{8}$ complexes are formed which can be represented in the form of the polymer chains (Fig. 9) [36]. Thus, nanoparticles hydroxide has a polymeric structural ordering. In these polymers formation of atoms $\mathrm{Zr}$ and $\mathrm{O}$ linked durable oxygen bonds and form the main chain. Lateral - the terminal groups are bonded less strong diol $(\mathrm{OH})$ and hydrogen $\left(\mathrm{H}_{2} \mathrm{O}\right)$ bonds. Polymer chains are linked by reacting the terminal groups (cross-linking polymerization).
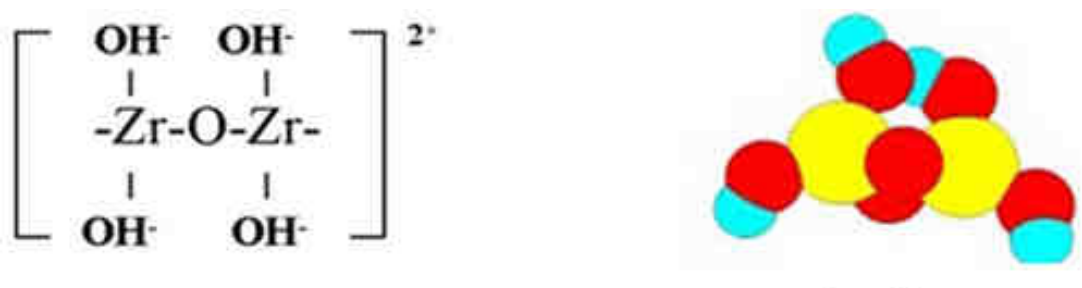

$$
\mathrm{i}=\mathbf{2}
$$
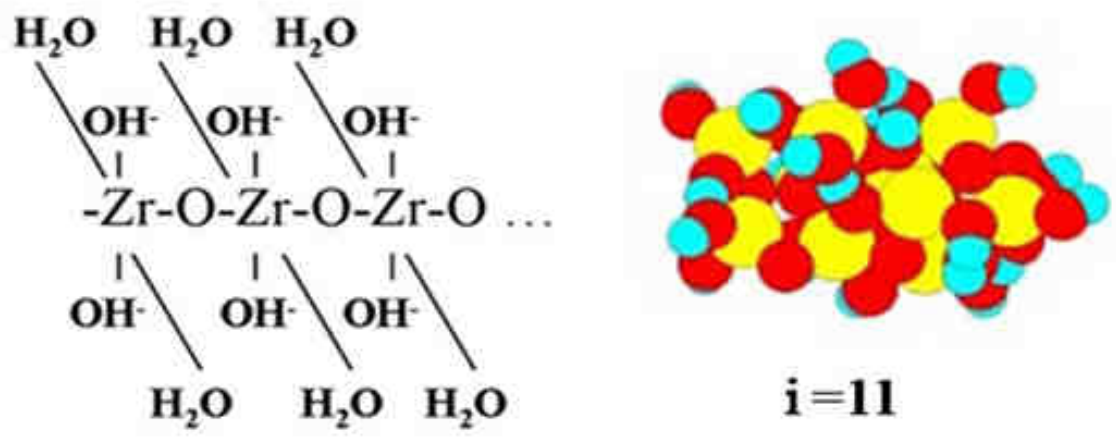

$$
\mathrm{i}=\mathbf{1 1}
$$

\section{$\mathrm{ZrO}(\mathrm{OH})_{2} \cdot \mathbf{n H}_{2} \mathrm{O}$}
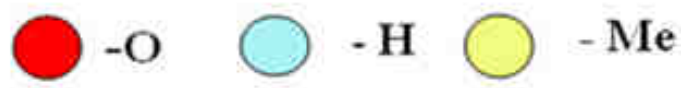

Fig. 9. Structure and molecular model of polynuclear groups and the polymer chains of $\mathrm{ZrO}(\mathrm{OH})_{2} \cdot \mathrm{nH}_{2} \mathrm{O}$ based thereon, where $\mathrm{i}$ - number of units

Structural organization of zirconia nanoparticles. Crystallization of polymer gel occurs by thermal destruction of terminal fragments of structural elements of the polymer matrix, ie, hydroxy-groups. As a result, desorption takes place of bound water and crosslinking the polymer chains in a regular crystal structure (Fig. 10). Thus, the oxide nanoparticles are derived from zirconium hydroxide nanoparticles, but have a more complete crystal structural regularity. 


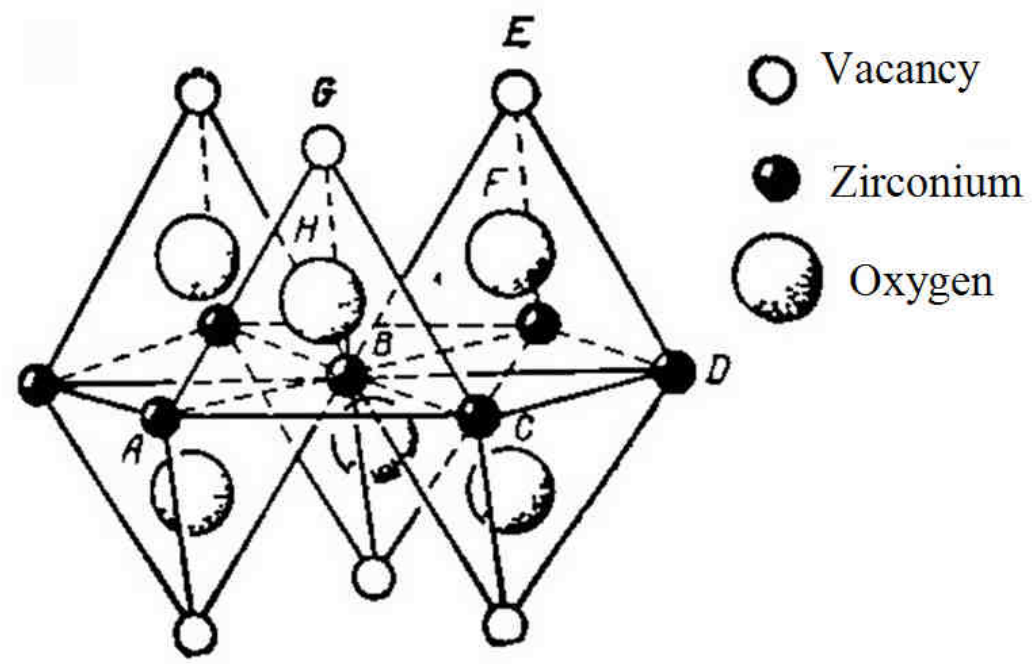

Fig. 10. The $\mathrm{ZrO}_{2}$ structural ordering regions presented in zirconium hydroxide on the stage of crystallization (from [39])

Polymer structure hydroxide is more inclined to transformation under the influence of external factors, and the particle surface coated with dimensions comparable layer of hydrated water - hydration shell. This in itself contributes to the interaction with biological objects. Furthermore, the specific surface area hydroxide $\left(S_{B E T}=300 \mathrm{~m}^{2} / \mathrm{g}\right)$ are in several times higher than that of the oxide $\left(S_{B E T}=80-120 \mathrm{~m}^{2} / \mathrm{g}\right)$ and, consequently, many times more the quantity of interfaces. That is, biocompatibility hydroxide nanoparticles by physical parameters must be higher than that of the oxide particles that actually observed experimentally.

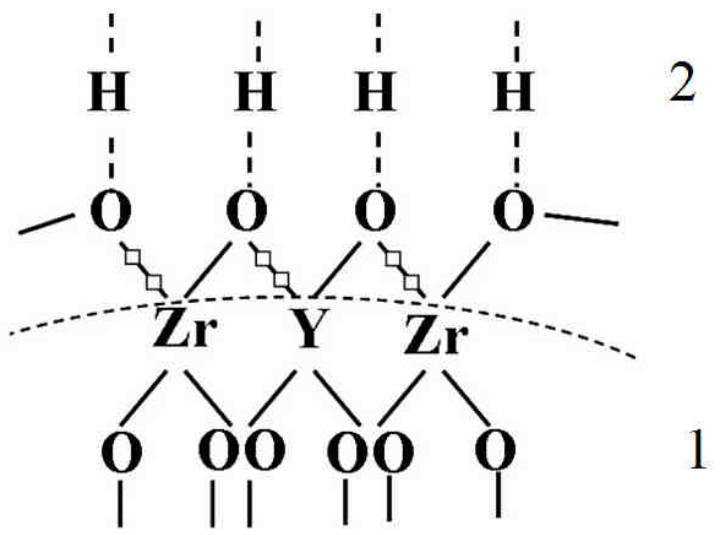

Fig. 11. The structure of chemisorbed hydrate layer on the surface of $\mathrm{ZrO}_{2}$ - nanoparticles. Numerals 1 and 2 note respectively the aggregate of base matter $\left(\mathrm{ZrO}_{2}\right)$ and chemisorbed ionic (OH- groups) layer 
Electrostatic mechanism of nanoparticles on biological tissues. Surface structure of the nanoparticles. Due to the dissociative adsorption of humidity [37] on coordinately unsaturated surface cations of nanoparticles the surface layer of OH-groups is forming (adsorption energy $>0.3 \mathrm{eV}$ [38]). This layer is presented in the form of bridging hydroxyl groups with "collectivized" oxygen [39] (Fig. 11).

The model suggests that the oxygen atoms are formally trivalent as for surface $\mathrm{Al}_{2} \mathrm{O}_{3}-\mathrm{SiO}_{2}$ [40], but not fixed to specific cations and spasmodically migrate across the surface of the nanoparticle. Therefore, the surface of the nanoparticles, firstly chemically is active and secondly - charged. Indeed, at the expense significant concentration at the surface uncompensated negatively charged ions in the solid solution composition $\mathrm{ZrO}_{2}-3$ mol \% $\mathrm{Y}_{2} \mathrm{O}_{3}$ surface charge is negative [41].

Obviously, the nanoparticles will selectively interact with ions of different kinds and electrostatic field on surface of the nanoparticles, in superposition with the electric field intercellular membranes will lead to a change of the transport properties of the latter. Physically bound water (binding energy $\mathrm{E}<40 \mathrm{~kJ} / \mathrm{mol}$ ) in the diffusion layer (Fig. 12) does not exhibit significant chemical activity but obviously plays an important role in the interaction of nano-powders with biological tissues. Significant content of aqueous component in hydroxide nanopowders about $30 \mathrm{wt} . \%$ and in zirconium dioxide nanopowders about 3-6 wt.\% [39] provides a relatively easy assimilation of their the biological cells.

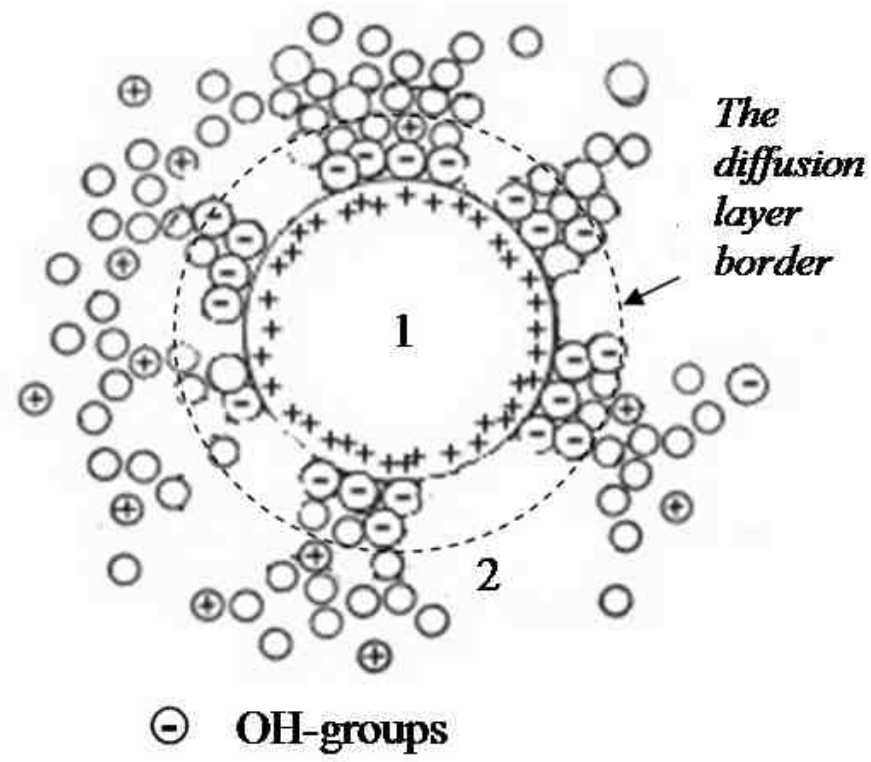

Fig. 12. Physical model of nanoparticles: the aggregate of base matter $\mathrm{ZrO}_{2}(1)$, and the ionic atmosphere (2)

Thus, from the analysis the surface structure of zirconia nanoparticles can distinguish on the degree of efficiency at least three factors impact oxide nanoparticles on the processes in biological tissues respectively: Electrostatic \& Chemical; Mechanical. The mechanisms of this 
impact are due electrophysical contact phenomenons and physicochemical processes mass exchange at the surface the nanoparticles. Biocompatibility and efficiency of particle interaction with biological tissues determined by the degree of penetration of the ions from tissue in the diffuse layer of particles, the degree of ordering of the crystal structure of the nanoparticles and the size factor.

\section{Conclusions}

Established that the addition of zirconium hydroxide $\left(\mathrm{ZrO}(\mathrm{OH})_{2}, \varnothing 4 \mathrm{~nm}\right)$ or zirconium oxide $\left(\mathrm{ZrO}_{2}-3 \mathrm{~mol} \% \mathrm{Y}_{2} \mathrm{O}_{3}, \varnothing 9 \mathrm{~nm}\right)$ nanoparticles at a concentration of 0.2 weight $\%$ in Czapek nutrient medium leads to an increase of 1.3-1.4 times (more than $2.6 \mathrm{~g} / \mathrm{dm}^{3}$ ) of biomass accumulation of mushroom and reducing 1.7-1.8 times the concentration of extracellular proteins into culture liquid at practically constant value of the final acidity ( $\mathrm{pH}$ change of the order of 2-5\%).

Established general characteristics morphobiological reaction to the implantation of oxide and hydroxide nanoparticles in samples of the mycelium mushroom $P$. ostreatus industrial strain HK-35 and natural isolates SA is to reduce transparency and increase the degree of compaction and the viscosity of the latter.

It is revealed differences character the response morphobiological reaction to the implantation of the nanoparticles in the samples of the mycelium mushroom P. ostreatus industrial strain HK-35 and natural isolates SA consisting in changing sorption capacity of the surface biomass. In particular, it is shown that the interaction nanopowders to the nutrient medium increases sorption capacity mushroom $P$. ostreatus, for the elements such as hafnium, zirconium, scandium, neodymium, mercury, thorium, cobalt, arsenic, strontium, silver, iodine, lanthanum, cerium, samarium, europium, and uranium in 2-1000 times. Identifying the ability mushroom can be used to obtain rare and valuable elements.

Detected low sorption capacity on media with nanopowders compared with control on manganese, nickel, copper, zinc, selenium, bromine, rubidium, strontium and cesium, indicates the incorporation of new mechanisms maintaining the livelihoods mushroom under the influence of this factor.

It was assumed the influence of nanopowders on the enzyme system mushroom, a form of manifestation which is more effective assimilation of the nutrient medium and the increase the amount of biomass.

Established that the concentration the elements $\mathrm{Fe}, \mathrm{Mg}, \mathrm{Ag}, \mathrm{Ni}, \mathrm{Co}, \mathrm{Al}, \mathrm{Ca}, \mathrm{Hg}, \mathrm{Sc}, \mathrm{V}$, $\mathrm{Sr}, \mathrm{La}, \mathrm{Ce}, \mathrm{Sm}, \mathrm{Eu}, \mathrm{Th}, \mathrm{Dy}$, and $\mathrm{U}$ was reliably higher than in control samples $P$. ostreatus. The level of accumulation of $\mathrm{Zr}$ and $\mathrm{Hf}$ is the highest among the long-lived elements. The concentration of these elements in the test sample relative to the control group samples strains HK- 35 and SA, respectively, amounts to $3.4 \cdot 10^{3}$ and $4.2 \cdot 10^{3}$ times.

Established that the physiologically important microelements $\mathrm{Zn}, \mathrm{Cu}, \mathrm{Mn}, \mathrm{Fe}$, and $\mathrm{Ni}$ in the group strain HK-35 are present in smaller quantities than in samples of the control group, while the strain SA concentrations differ several times.

It is concluded the functioning of the mechanism detoxification of harmful elements and the direct participation of $\mathrm{Zr}$ in these processes.

Based on the data of neutron activation analysis for metals $\mathrm{Hg}, \mathrm{Ag}, \mathrm{Nd}$, and $\mathrm{Sc}$ was concluded that detoxification function in industrial mushroom P. ostreatus strain HK-35 is better developed than in native strain SA. 
Based on the data of neutron activation analysis relatively concentration of monovalent ions $\mathrm{K}, \mathrm{Na}, \mathrm{Cl}$ has been suggested that the mechanism of physical modification tissue mushroom associated with a change of the ion-transport functions of intercellular membranes.

It is suggested that the role of zirconium as other metal with a variable oxidation state $(\mathrm{Cu}, \mathrm{Fe})$ when implementing a biological system functions detoxification might be in promoting processes joining of electrons to oxygen with the further formation of active forms - superoxide radical, hydroxy radical, singlet oxygen and others.

It is suggested possibility of using the protein enriched AFC synthesized in nanoparticles physically modified biological system, in particular mushroom $P$. ostreatus, in medicine for the treatment of diseases, such as gastric cancer.

It was established that the degree structural ordering nanoparticles added into cultivation medium make essential impact on mineral composition of the surface of the mycelium mushroom $P$. ostreatus.

It is shown that nanoparticles of zirconium hydroxide has lower the degree of structural organization than nanoparticles of zirconium oxide, more developed and more hydration phase interface surface and therefore give a more pronounced effect on the processes ontogeny in biological tissues.

It is concluded that the mechanisms of effects of the interaction of nanoparticles with biological tissues are associated with electrophysical contact phenomenons and physicochemical processes mass exchange at the surface the nanoparticles.

The practical value. Experimental data indicate that the use of low concentrations of oxide nanoparticles perspective allow with minimal cost increase yield and crop resistance to diseases of 1.5 times and may also be used in the development of heavy metals sorbents and anticancer drugs.

\section{References}

[1] Sergeev GB. Nanochemistry. Moscow: Publishing House of Moscow State University; 2003. http://booksplanet.info/knigi-po-tochnym-i-estestvennym-naukam/knigi-po-himii/826-sergeev-g-bnanohimija.html.

[2] Uaitsaids D, Eigler D, Anders R. Nanotechnology in the coming decades. Forecast research directions. In: Roco MK, Williams RS, Alivisatos P, editors. Nanotechnology Research Directions: IWGN Workshop Report: Vision for Nanotechnology in the Next Decade, Dordrecht: Kluwer Acad Publ; 2000.

[3] Galindo TPS, Pereira R, Freitas AC, Santos-Rocha TA, Rasteiro MG, Antunes F, at al. Toxicity of organic and inorganic nanoparticles to four species of white-rot fungi. Sci Total Environ. 2013;458-460:290-297. DOI: 10.1016/j.scitotenv.2013.04.019.Epub2013May8. http://www.sciencedirect.com/science/article/ pii/S0048969713004403.

[4] Doroshkevich NV, Frontasyeva MV, Doroshkevich VS, Shylo AV, Ostrovnaya TM, Pavlov SS, et al. Interaction of P. ostreatus (Jacq.: Fr.) Kummer mushroom with zirconium oxide nanoparticles. Annual report FLNP JINR. 2014;103-107. http://flnp.jinr.ru/img/304/1257_Nuclear_Physics_reports.pdf.

[5] Zholobak NM, Ivanov VK, Shcherbakov AB, Shaporev AS, Polezhaeva OS, Baranchikov AYe, et al. UV-shielding property, photocatalytic activity and photocytotoxicity of ceria colloid solutions. J Photochem Photobiol B: Biol. 2011;102(1):32-38. DOI: 10.1016/j.jphotobiol.2010.09.002.

[6] Spivak NYa, Shepel EA, Zholobak NM, Shcherbakov AB, Antonovitch GV, Yanchiy RI, et al. Ceria nanoparticles boost activity of aged murine oocytes. Nano Biomedic Eng. 2012;4:4:188-194. DOI: 10.5101/nbe.v4i4.p188-194.

[7] Bhat R, Sharanabasava VG, Deshpande R, Ullas Shetti, Sanjeev G, Venkataraman A. Photo-bio-synthesis of irregular shaped functionalized gold nanoparticles using edible mushroom Pleurotus florida and its anticancer evaluation. J Photochem Photobiol B: Biol. 2013;125:63-69. DOI: 10.1016/j.jphotobiol.2013.05.002. 
[8] Roy N, Gaur A, Jain A, Bhattacharya S, Rani V. Green synthesis of silver nanoparticles: An approach to overcome toxicity. Environ Toxicol Pharmacol. 2013;36(3):807-812. DOI: 10.1016/j.etap.2013.07.005. ttp://www.sciencedirect.com/science/article/pii/S138266891300152X.

[9] Sarkar QJ, Roy SK, Laskar A, Chattopadhyay D, Acharya K. Bioreduction of chloroaurate ions to gold nanoparticles by culture filtrate of Pleurotus sapidus. Materials Lett. 2013;92:313-318. DOI: 10.1016/j.matlet.2012.10.130.

[10] Baldrian P, Gabriel J. Nerud F, Zadrazil F. Effect of heavy metals on the growth of selected wood-rotting Basidiomycetes. Folia Microbiol. 1997;42(5):521-523. DOI: 10.1007/BF02826566.

[11] Gorbunov AV, Lyapunov SM, Mochalova E, Frontasyeva MV, Pavlov SS. Assessment of factors influencing trace element content of the Basidiomycetes in the European part of Russia. Adv Microbiol. 2013;3:37-46. DOI: 10.4236/aim.2013.38A007. http://dx.doi.org/10.4236/aim.2013.38A007.

[12] Lamrood PY, Ralegankar SD. Biosorption of $\mathrm{Cu}, \mathrm{Zn}, \mathrm{Fe}, \mathrm{Cd}, \mathrm{Pb}$ and $\mathrm{Ni}$ by non-treated biomass of some edible mushrooms. Asian J Exp Biol Sci. 2013;4(2):190-195. http://www.ajebs.com/vol4(2)/5.pdf.

[13] Silva SO, Gomes da Costa SM, Clemente E. Chemical composition of Pleurotus pulmonarius (Fr.) Quél., substrates and residue after cultivation. Braz Arch Biol Technol. 2002;45(4):531-535. http://dx.doi.org/10.1590/S1516-89132002000600018.

[14] Krasnopolskaya LM, Belitsky I, Feodorova G. Screening of strains of the genus Pleurotus (Fr.) Kumm. with a broad spectrum of antimicrobial activity. Int $\mathbf{J}$ Med Mushrooms. 2001;3:172. http://www.dl.begellhouse.com/download/article/5cb6075c2e20cd80/IJM\%200302-3\%20(172).pdf.

[15] Lindequist U, Niedermeyer THJ., Jülich WD. The pharmacological potential of mushrooms. Evid Based Complement Alternat Med. 2005;2-3:285-299. DOI: 10.1093/ecam/neh107.

[16] Kocaoba S, Arssoy M. The use of white-rot fungi (Pleurotus ostreatus) immobilized on amberlite XAD-4 as a new biosorbent in trace metal determination. Biores Technol. 2011;102:8035-8039. DOI: 10.1016/j.biortech.2011.05.004 (http://europepmc.org/abstract/MED/21737258).

[17] Lan Ma, Yuhong Peng, Bo Wu, Daiyin Lei, Heng Xu. Pleurotus ostreatus nanoparticles as a new nano-biosorbent for removal of $\mathrm{Mn}$ (II) from aqueous solution. Chem Eng J. 2013;225:59-67. DOI 10.1016/j.cej.2013.03.044.

[18] Pazur A, Rassadina V, Dandler J, Zoller J. Growth of etiolated barley plants in weak static and $50 \mathrm{~Hz}$ electromagnetic fields tuned to calcium ion cyclotron resonance. Biomagn Res Techn. 2006;4:1. DOI:10.1186/1477-044X-4-1 http://www.biomagres.com/content/4/1/1.

[19] Bilay VI. Methods of Experimental Mycology. Kiev: Naukova Dumka Press; 1982. http://booksshare.net/index.php?id1=4\&category=biol\&author=bilay-vi\&book=1982\&.

[20] Semenov SM. Laboratory Media for Actinomycetes and Fungi. Moscow: Agropromizdat; 1990. http://www.thetoptube.com/the-big-forum/topic-t327726.html.

[21] Kochetov GA. A Practical Guide to Enzymology. Moscow: Higher School; 1980.

[22] Frontasyeva MV, Kirkesali EI. Epithermal neutron activation analysis in applied microbiology. J Rad Nucl Chem. (Specil issue of MTAA-13 Proceedings, March 13-18, 2011, College Station, Texas, USA.) 2010;286(2):519-524. http://www.springerlink.com/content/p730m22h7h2605x3.

[23] Frontasyeva MV, Pavlov SS, Shvetsov VN. NAA for applied investigations at FLNP JINR: present and future. J Rad Nucl Chem. 2010;286:519-524. DOI 10.1007/s10967-010-0814-z.

[24] Frontasyeva MV. NAA for life sciences at Frank Laboratory of Neutron Physics, Joint Institute for Nuclear Research in Dubna. Ecol Chem Eng S. 2011;18(3):281-304. http://tchie.uni.opole.p1/freeECE/S_18_3/Frontasyeva_18(S3).pdf.

[25] Cole MA, Voelcker NH, Thissen H, Griesser HJ. Stimuli-responsive interfaces and systems for the control of protein-surface and cell-surface interactions. Biomaterials. 2009;30:1827-1850. http://www.researchgate.net/profile/Nicolas_Voelcker/publication/23788505_Stimuli-responsive_pdf.

[26] Parshina AV, Bobreshova OV, Titov TS. Influence of zirconium oxide(IV) on the sensitivity PD-sensors based on perfluorinated membranes to anions of glycine, alanine and leucine in alkaline solutions. Sorpt Chromatogr Process. 2014;14(3):428-433. http://www.chem.vsu.ru/sorbcr/images/pdf/2014/3/ 2014_03_09.pdf.

[27] Becker HE. Physiology and Biochemistry of Fungi. Moscow: University Press; 1988. http://www.biocat.ru/ebook.php?file=bekker_grib.djvu\&page $=1$.

[28] Gorbunov AV, Lyapunov SM, Okina OI, Frontasyeva MV, Pavlov SS. Nuclear and related analytical techniques in ecology: impact of geoecological on the balance of trace elements in the human organism. Phys Particl Nucl. 2012;43(6):783-824. http://dx.doi.org/10.1134/S1063779612060044.

[29] Gorbunov AV, Lyapunov SM, Okina OI, Frontasyeva MV, Gundorina SF. Estimation of income micronutrients the human body with food in the central regions of Russia. [Preprint Moscow. Dubna: Joint 
Institute for Nuclear Research. D14-2004-89; 2009. http://www1.jinr.ru/Preprints/2004/089(D14-200489)_e.pdf.

[30] Bilai VI. Foundations of General Mycology. Kiev: Higher School; 1980.

[31] Alfarra RS, Ali NE, Yusoff MM. Removal of heavy metals by natural adsorbent: review. Int J Biosci. 2014;4(7):130-139. http://dx.doi.org/10.12692/ijb/4.7.130-139.

[32] Struchkova IV, Brilkina AA, Veselov AP. Regulation of Protein Synthesis. Educational Handbook. Nizhny Novgorod: Nizhny Novgorod State University; 2010. http://www.unn.ru/books/met_files/reg_bios_belka.pdf.

[33] Swodoba L, Zimmermanova K, Kalac P. Concentrations of mercury, cadmium, lead and copper in fruiting bodies of edible mushrooms in an emission area of copper smelter and a mercury smelter. Sci Total Environ. 2000;246:61-67. http://kch.zf.jcu.cz/vyzkum/publikace/separaty/2000-0067.pdf.

[34] Implants for surgery - Biocompatibility - Selection of biological test methods for materials and devices ISO/TR 9966: 1989 (E).

[35] Buyanov RA, Kryvoruchko OP. Development of the theory of crystallization of sparingly soluble metal hydroxides and scientific foundations of catalyst preparation of compounds of this class. Kinet Catal. 1976;17(3):765-775. http://www.twirpx.com/file/1099318.

[36] Elinson SV, Petrov KI. Analytical chemistry of zirconium and hafnium. Jerusalem: Israel Program for Scientific Translations; 1965. http://pi.lib.uchicago.edu/1001/cat/bib/816149.

[37] Lisichkin GV. Chemical modification of the surface of the mineral. Soros Educ J. 1996;4:52-59. http://www.pereplet.ru/nauka/Soros/pdf/9604_052.pdf.

[38] Akopyan ME. Molecular photoprocesses at the gas-solid. Soros Educ J. 1998;2:115-120. www.pereplet.ru/nauka/Soros/pdf/9802_115.pdf.

[39] Strekalovsky VN, Polezhaev YM, Palguev SF. Oxides with Impurity Disordering. Moscow: Nauka; 1987.

[40] Patrilyak LK. Catalytic cracking: practice and theory, the development of research in Ukraine. Catalysis Chemicals. 2001;9-10:14-25. dspace.nbuv.gov.ua/handle/123456789/4047.

[41] Alexeenko VI, Volkova GK.. The adsorption mechanism of phase transformation of stabilized zirconium. J Techn Phys. 1999;70(9)57-62. http://www.e-biblioteka.lt/resursai/Uzsienio\%20leidiniai/ioffe/ztf/2000/09/ ztf_t70v09_10.pdf.

\title{
WPLYW NANOCZĄSTEK CYRKONU NA PARAMETRY MORFOFIZJOLOGICZNE I SKŁAD MINERALNY P. ostreatus
}

\begin{abstract}
Abstrakt: Zastosowanie neutronowej analizy aktywacyjnej w badaniach Pleurotus ostreatus pokazało, że dodawanie stałego roztworu wodorotlenku i tlenku $\mathrm{ZrO}_{2}-\mathrm{Y}_{2} \mathrm{O}_{3}\left(3 \mathrm{~mol} \% \mathrm{Y}_{2} \mathrm{O}_{3}\right)$ w postaci nanocząstek o rozmiarze 4 i $9 \mathrm{~nm}$ w stężeniu $0,2 \%$ wagowych w pożywce (Czapek) zmienia charakter procesów fizjologicznych w tkankach biologicznych grzybów. Zjawisko to przejawia się w postaci znacznych zmian morfologicznych i fizjologicznych cech grzybów oraz składu pierwiastkowego suchej biomasy. W szczególności wykazano, że wprowadzenie nanocząstek do tkanek grzybów prowadzi do wzrostu 1,3-1,4 razy (więcej niż 2,6 $\mathrm{g} / \mathrm{dm}^{3}$ ) akumulacji biomasy (szczep przemysłowy HK 35) i spadku o 1,7-1,8 razy (poniżej 1,7-2,5 mg/mm ${ }^{3}$ ) stężenia pozakomórkowych białek w płynie hodowli przy zasadniczo stałej wartości kwasowości. Pokazano, że dodanie $\mathrm{ZrO}_{2}+3 \%$ mol nanocząstek $\mathrm{Y}_{2} \mathrm{O}_{3}$ rozmiarów 4 lub $9 \mathrm{~nm}$ do tkanki grzyba na etapie grzybni macierzystej, w bardzo małych stężeniach, może skutecznie zmieniać skład chemiczny substancji wytwarzanych przez komórki, a co za tym idzie, jej aktywność fizjologiczną. Wykazano, że stosowanie niskich stężeń nanocząstek $\mathrm{ZrO}_{2}$ zwiększa wydajności i podnosi odporności roślin na choroby do 1,2-1,5 raza, a także w przyszłości może być stosowane w technologii biomedycznej, w leczeniu chorób nowotworowych.
\end{abstract}

Słowa kluczowe: neutronowa analiza aktywacyjna, grzyb $P$. ostreatus (Jacq.: Fr.) Kummer, interakcje nanocząsteczek z tkankami biologicznymi, sorbenty metali ciężkich, leki przeciwnowotworowe 